\title{
KAJIAN SEMIOTIKA KONOTASI ROLAND BARTHES PADA FOTO WANITA JAWA PADA KARTU POS TAHUN 1900-1910
}

\author{
Lelyana Septianti Soetarjo
}

Fakultas Media Rekam, Institut Seni Indonesia Yogyakarta

e-mail : lelysoetarjo@gmail.com

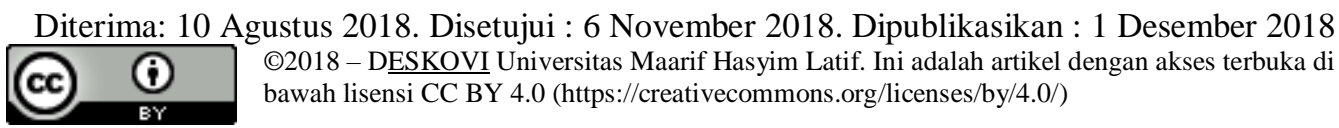

\begin{abstract}
ABSTRAK
Penelitian ini mengkaji makna konotasi pada potret wanita Jawa dalam kartu pos tahun 1900-1910 dengan menggunakan landasan teori yaitu semotika Roland Barthes. Prosedur penemuan konotasi antara lain trick effect, pose, objek, fotogenia (cahaya, nada, bayangan, bentuk, garis, tekstur, perspektif, dan ruang). Tujuan dari penelitian ini adalah untuk menjelaskan makna yang tersirat pada foto potret wanita Jawa dengan memperhatikan aspek fotogenia dan konotator yang terdapat dalam foto guna menuntun pemaknaan pada karya fotonya
\end{abstract}

Kata kunci: kartu pos, konotasi, semiotika, wanita jawa.

\section{ABSTRACT}

This study examines the connotation meaning in portraits of Javanese women on postcards in 1900-1910 using the theoretical foundation of Roland Barthes's semotic. The procedure for finding connotations includes trick effects, poses, objects, photogenia (light, tone, shadow, shape, line, texture, perspective, and space). The purpose of this study is to explain the meaning implied in a portrait of a Javanese woman by taking into account the photogenia and connotator aspects contained in the photo to guide the meaning of her photographic work

Keywords: Postcards, Connotations, Semiotics, Javanese women.

\section{PENDAHULUAN}

Pada awal penemuannya fotografi lebih banyak digunakan sebagai alat bantu melukis karena kemampuan reproduksi imaji dengan presisi tinggi yang menjadi daya tarik bagi para pelukis pada saat itu. Sebagai media yang terbilang baru saat itu, fotografi dianggap akan menggantikan kejayaan seni lukis yang terlebih dulu muncul. Hal ini diperkuat dengan pernyataan salah seorang pelukis Perancis, De la Roche bahwa: "From today painting is dead.". (Soedjono, 2006, p. 4)

Pada tahun 1839 dua teknik fotografi diberikan pada dunia yaitu daguerreotypy dan talbotypy. Hingga akhirnya fotografi masuk ke Nusantara pada tahun 1941, hanya berselang dua tahun semenjak fotografi diplokamirkan yang saat itu bernama Hindia Belanda. Fotografi diperkenalkan di Jawa menjelang ujung abad-19 oleh Isidore Van Kinsbergen, seorang fotografer yang yang bekerja di Jawa Tengah sekitar tahun 1863-1875. Masyarakat Jawa yang sempat menyaksikan dan merasakan peristiwa tersebut adalah Kassian Cephas, merupakan seorang pribumi Jawa yang mendapatkan kesempatan untuk menikmati dan sekaligus mempelajari masuknya peradaban barat dan teknologi dalam kehidupan masyarakat Jawa, khususnya di Yogyakarta.

Publikasi foto-foto Kassian Cephas di mulai tahun 1888, pada saat membantu Isaac Groneman yang datang ke Yogyakarta pada 1869. Isaac Groneman merupakan salah satu dari pendiri dan anggota Vereeninging voor Oudheid-Land-Tall-en Volkenkunde te Jogjakarta, atau perkumpulan arkeologi, geografi, bahasa, dan etnografi Yogyakarta. Kassian Cephas menjadi anggota perkumpulan ini dan menjadi juru foto dalam banyak penelitian, baik yang dilakukan oleh perkumpulan maupun Groneman secara pribadi (Knaap, 1999, p. 8).

Pada tahun 1892 Kassian Cephas yang merupakan fotografer di Yogyakarta menjadi salah satu pionir dan fotografer pribumi pertama kali yang diangkat menjadi fotografer resmi Keraton Ngayogyakarta Hadiningrat dalam pemerintahan Sultan Hamengkubuwana VII. Kedekatannya dengan pihak keraton membuat ia bisa memotret momen- 
momen khusus yang hanya diadakan di keratin, seperti keluarga sultan, tari-tarian klasik, putri-putri kerajaan, tidak hanya dengan keluarga keraton, Cephas juga banyak mendokumentasikan kehidupan masyarakat pada saat itu. Keberhasilannya memperlihatkan perjalanan sejarah sedemikian nyata dalam bentuk karya foto yang banyak sekali dicetak dalam kartu pos, serta menunjukkan fakta bahwa transformasi teknologi berjalan seiring perjalanan sejarah kebudayaan yang berkembang, khususnya di tanah Jawa (Raap, 2013, p. 171)

Perkembangan fotografi melahirkan banyak genre yang memiliki keunggulan dan daya tarik tersendiri bagi landasan berkarya oleh pelakunya. Seperti pada banyak karya foto yang diterbitkan pada kartu pos era Hindia Belanda. Foto potret banyak ditampilkan seperti, potret keluarga bangsawan hingga pribumi pada saat itu. Potret sendiri merupakan salah satu genre fotografi yang banyak digunakan pada masa Hindia Belanda, fotografi potret sendiri merupakan hasil representasi perekaman/pengabadian „likeness" (kemiripan) jati diri atau figur manusia dalam bentuk dwimatra (gambar) (Soedjono, 2006, p 111). Sedangkan dalam sejarah fotografi Indonesia, dimulai dari Kassian Cephas yang memulai fotografi potret. Tradisi fotografi potret ini berlanjut sampai abad XX yang menceritakan fenomena munculnya studio-studio foto di berbagai penjuru di Indonesia yang didominasi oleh kaum non-pribumi: Belanda, China, Jepang (zaman pendudukan Jepang) (Soedjono, 2006, p. 116)

Seiring berjalannya waktu, terjadi perubahan fungsi fotografi di Hindia Belanda. Fotografi yang semula untuk kepentingan ilmiah menjadi komersil. Fotografi, saat itu memungkinkan warga Eropa yang tinggal di Nusantara untuk memiliki potret diri, menggantikan lukisan yang saat itu menjadi lambang status sosial. Para elite Eropa sering mendatangi studio foto atau mendatangkan para fotografer ke rumah. Mulanya, sebagaian besar pesanan pembuatan foto potret pada saat itu memang hanya berasal dari golongan elite Eropa saja. Namun, para fotografer mencoba mencari peruntungan dengan menawarkan jasa mereka ke kalangan elite Jawa dengan menerbitkan iklan-iklan di berbagai surat kabar lokal. Menyebut bahwa foto dapat menyiratkan status golongan dan modernitas, hubungan yang baik dengan bangsa Eropa, serta hierarki keluarga dan komunitas, sebab hanya raja (Surakarta dan Yogyakarta) serta bangsawan yang lebih rendah setingkat bupati saja yang bisa membuat foto potret. Tak hanya foto potret laki-laki saja, wanita Jawa (istri dan anggota keluarga kerajaan) juga membuat foto potret mereka.

Kartu pos menjadi media komunikasi populer sekitar permulaan abad ke-20, kartu pos dipakai untuk menyampaikan berita-berita pendek. Menurut Kamus Besar Bahasa Indonesia kartu pos adalah selembar kertas tebal atau karton tipis berbentuk persegi panjang yang digunakan untuk surat menyurat melalui pos (tidak bersampul). Kartu pos awalnya tidak dilengkapi dengan gambar, satu sisi kosong digunakan untuk menulis pesan dan sisi baliknya digunakan untuk menulis alamat penerima dengan prangko yang telah tercetak. Kartu pos generasi pertama di Indonesia diterbitkan tahun 1874 oleh pos negara dalam pemerintahan Hindia Belanda yang tidak dilengkapi dengan gambar (lukisan maupun foto). Pada sekitar tahun 1890, penerbit- penerbit swasta yang tidak terkait dengan pos negara mulai membuat kartu pos bergambar. Secara umum terdapat tiga kategori kartu pos pada abad ke-20 yang menggambarkan pulau Jawa. Kategori pertama berisi bagian-bagian kota yang modern dengan latar hasil karya pendatang kolonial, kategori kedua mewakili pemandangan alam serta kategori ketiga menggambarkan kebudayaan tradisional penduduk lokal (Raap, 2013, p. 171).

Kegunaan kartu pos pada saat itu sudah mulai bergeser dari alat komunikasi menjadi kartu koleksi yang sangat digemari kaum nonpribumi. Latar belakang kehidupan pribumi menjadi daya tarik tersendiri bagi para kolektor kartu pos. Pasalnya kartu pos bertema gadis pribumi banyak dicari pada saat itu. Terhitung lebih banyak model wanita daripada lakilaki. Biasanya diabadikan karena status pekerjannya atau kelas sosial, wanita dari kalangan keluarga bangsawan mereka biasa mengundang fotografer untuk datang ke kediaman mereka, berbeda dengan wanita dari kalangan nonelite yang tak mampu membayar biaya pemotretan yang mahal. Biasanya fotograferlah yang mengundang wanita tersebut ke studio dan mendapat bayaran atas jasa mereka, tapi belum tentu mereka dapat melihat hasil fotonya, yang kemudian foto tersebut banyak dijual kepada penerbit kartu pos (Raap, 2013, p. 15). Persepsi tentang wanita Jawa pada saat itu sebagai sisi lain keeksotisan dari Jawa sangatlah besar. Potret-potret wanita Jawa pada kartu pos saat itu pada dasarnya menjadi daya tarik tersendiri tentang sebuah keeksotisan.

Foto merupakan gambar diam berwarna maupun hitam putih yang dihasilkan oleh kamera yang merekam suatu objek atau kejadian atau keadaan pada suatu waktu tertentu. Wanita Jawa merupakan salah satu objek yang sering diabadikan oleh para fotografer pada masa penjajahan di Jawa sekitar awal tahun 1900, selain tentunya mereka banyak juga mendokumentasikan sosok masyarakat lokal, arsitektur, kebudayaan, kesenian, dan lain sebagainya. Foto wanita Jawa pada saat itu sering dijumpai pada kartu pos bergambar.

Sampai saat ini belum ada kesepakatan dalam penggunaan istilah (yang tepat) perempuan atau wanita. Kata perempuan berasal dari empu, bermakna dihargai, dipertuan, atau dihormati. Kata wanita diyakini dari Bahasa Sansekerta, dengan dasar kata wan yang berarti nafsu, sehingga kata wanita mempunyai arti yang dinafsui. Wanita berarti wani ditata, artinya berani ditata dan wanita juga berasal dari kata wani tapa yang artinya wanita adalah sosok yang berani menderita bahkan untuk orang lain. Jadi 
secara simbolik mengubah penggunaan kata wanita menjadi perempuan adalah mengubah objek menjadi subjek. Kedua istilah ini tidak hanya berkaitan dengan asal bahasa atau padanan kata saja, tetapi berkaitan dengan citra, mitos, atau stereotip. Oleh karena itu, kaum feminis (di Indonesia) kebanyakan memilih menggunakan kata perempuan dan bukan wanita (Handayani \& Novianto, 2004).

Dalam penelitian ini menggunakan kata wanita karena berdasarkan pemaknaan kata "wanita" lebih dekat dengan kesadaran praktis masyarakat Jawa. Bahwa kata wanita berasal dari kata wani (berani) ditata (diatur), jadi wanita Jawa adalah orang yang berani diatur. Namun demikian, bukan berarti pasif dan tergantung kepada orang yang mengaturnya. Sedangkan istilah "perempuan" tampaknya tidak cukup bisa menggambarkan kenyataan praktis seharihari wanita Jawa. Akar kata perempuan adalah empu yang berarti guru, makna kata ini lebih menggambarkan kenyataan normatif daripada kenyataan praktis sehari-hari. Karakter wanita Jawa sangat identik dengan kultur Jawa, seperti bertutur kata halus, tenang, kalem, tidak suka konflik, mementingkan harmoni, menjunjung tinggi nilai keluarga, sopan, pengendalian diri tinggi/terkontrol, setia/loyalitas tinggi.

Dalam serat wulang putri, wanita Jawa kuno mampu melakukan olah kebatinan dengan tekun dan digunakan secara total untuk diri dan keluarganya. Keutamaan karakter wanita Jawa yang selalu mengutamakan sabar, darma, lila, legawa, dan narima ing pandum, mempunyai makna yang dalam. Wanita adalah sebuah entitas yang indah, rumit, sekaligus menarik. Sosoknya sebagai pendamping dan pembanding laki-laki membuatnya menjadi sosok yang seolah hanya sebagai makhluk kedua yang berdiri dibelakang laki-laki sebagai kanca wingking atau teman dibelakang, tanpa memiliki kekuasaan sama sekali.

Pakaian sehari- hari wanita Jawa umumnya adalah kemben yang dipadukan dengan stagen dan juga kain jarik. Kemben digunakan untuk menutupi payudara dan ketiak. Sementara stagen dililitkan pada bagian perut sebagai kain pengikat agar kuat dan tidak mudah lepas. Kemben biasanya digunakan oleh wanitawanita pribumi yang berasal dari kelas sosial terendah seperti pedagang- pedagang kecil, pembantu rumah tangga, serta akrab pula dengan sebagaian wanita yang menjalani profesi sebagai tuna susila yang terlihat pada foto- foto pada tahun 1860 sampai 1900-an memperlihatkan pemakaian kemben yang dikombinasikan dengan kain jarik atau lurik (Irwandi \& Apriyanto, 2012, p. 80). Berdasarkan pemaparan di atas, maka dalam penelitian ini akan membahas foto potret wanita Jawa dalam kartu pos tahun 1900-1910. Foto potret wanita Jawa mempunyai makna yang menarik untuk diteliti, sekilas pandang dalam kartu pos yang menggunakan objek wanita Jawa memiliki makna tersirat yang ditampilkan, seperti dari pose, ekspresi wajah, dan pakaian yang digunakannya.
Namun, bila ditelusuri lebih jauh, maka kita akan mendapatkan sebuah makna yang terkandung dalam foto tersebut. Meskipun dalam kultur Jawa, wanita sangat dibatasi ruang geraknya. Melalui fotografi dapat diperoleh beragam gambaran yang dapat menjelaskan sisi lain para wanita Jawa, mengenai posisi sosial, peran, bahkan citra. Maka dari itu, potret wanita Jawa sangat menarik untuk dijadikan bahan kajian. Untuk mengetahui makna tersebut, penulis merasa perlu untuk melakukan kajian semiotika konotasi Roland Barthes.

Peranan media sangat penting dilibatkan dalam pencitraan budaya Jawa sebagai daerah yang harmonis dan kental akan tradisi budaya. Pada masa kolonial Belanda tepatnya awal abad ke 20 media kartu pos bergambar digunakan untuk mempublikasi dan menggambarkan citra Jawa. Berdasarkan identifikasi dan lingkup masalah, maka diperoleh rumusan masalah yaitu ; bagaimanakah makna konotasi pada objek wanita Jawa dalam kartu pos tahun terbit 1900- 1910 ditinjau dari kajian semiotika Roland Barthes ?

Roland Barthes menyebut bahwa, sebuah foto adalah "pesan berkode". Menurut Barthes, sebuah foto beroperasi sebagai sistem tanda. Seperti dalam semiotika, tanda sebenarnya memiliki arti eksistensial (hadir). Karena itulah pemaknaan fotografi tak bisa dilepaskan dari konteks yang mengelilinginya (Barthes, 1981:52). Aspek formal fotografi digunakan sebagai bahan analisis foto untuk mendukung semiotika fotografi dalam mengetahui makna yang terdapat dalam foto, sehingga dapat mengungkap makna yang terlampir pada foto wanita Jawa. Karena itu, pemaknaan dalam gambar wanita Jawa dapat dipahami melalui keseluruhan informasi yang didapatkan melalui penanda gambar. Sudut pandang dilakukan untuk membongkar tanda yang memiliki makna denotasi dan konotasi pada objek penelitian.

Berdasarkan rumusan masalah yang telah dipaparkan di atas, maka tujuan dari penelitian antara lain adalah untuk mengetahui makna konotasi yang terkandung dalam foto potret wanita Jawa pada tahun 1900-1910, sedangkan manfaat dari penelitian ini antara lain penelitian ini diharapkan memperkaya wacana pengkajian fotografi berlatar belakang kebudayaan Jawa khususnya pada wanita Jawa, dapat memberikan kontribusi yang positif bagi mahasiswa maupun masyarakat dalam perkembangan ilmu fotografi ditinjau dari analisis semiotika, menjadi bahan dan wawasan dalam ilmu pengkajian analisis fotografi dan sebagai sumber rujukan ilmiah, bagi penulis, penelitian ini dapat mengasah kemampuan berpikir secara ilmiah dengan menganalisis data dari objek yang dikaji.

Penelitian dengan objek wanita Jawa sering dijadikan bahan penelitian lainnya. Penelitian yang berkaitan dengan skripsi ini telah ditemukan dan dianalisis, baik itu berupa skripsi maupun jurnal. Dari hasil penelitian yang sudah dilakukan tersebut kemudian dijadikan sebagai bahan referensi untuk 
tinjauan pustaka, sehingga dapat diketahui apa saja persamaan maupun perbedaan yang terdapat dalam penelitian.

Sebuah skripsi dengan latar belakang perempuan Jawa pada masa kolonial sebagai subjek kajian pernah ditulis oleh Widya Fitrianingsih dari jurusan Ilmu Sejarah UGM. Kajiannya itu berjudul "Perempuan dalam Iklan Media Cetak di Jawa pada Masa Kolonial (1900-1942)" (2008). Dalam tulisannya, Widya membahas representasi perempuan dalam iklan media cetak sepanjang tahun 1900-1924 dengan kesimpulan bahwa, media cetak berhasil menggunakan citra perempuan sebagai alat penjual iklan, baik dalam bentuk foto maupun dalam ilustrasi. Perbedaan penelitian ini dengan penelitian Widya adalah media yang dijadikan dasar studi, penelitian ini menggunakan fotografi sebagai dasar penelitian, sementara Widya menggunakan gambar cetak dan ilustrasi.

(Sahid, 2004) dalam penelitiannya yang berjudul "Wanita- Wanita Korban Peradaban Priyayi Jawa dalam Beberapa Karya Naratif Indonesia: Sebuah Kajian Sosiologi Sastra”. Dalam penelitiannya terdapat kesamaan objek yaitu wanita Jawa era Hindia Belanda. Penelitian ini sangat fokus akan kritik feminis pada masa itu, banyak wanita Jawa yang menjadi gundik Belanda maupun bangsawan lokal. Perbedaan penelitian ini dengan penelitian Nur Sahid adalah penelitian sastra dan penelitian fotografi.

(I Wayan, 2016) dalam penelitian tesisnya yang berjudul "Kajian Semiotika Pada Poster Bali di Masa Kolonial Belanda tahun 1920-1942" juga menggunakan latar belakang wanita dalam penelitiannya. Hasil dari penelitian tersebut adalah keeksotisan dari wanita Bali pada saat itu dan kebudayaaan Bali yang dianggap masih sangat asli menjadi daya tarik bagi para turis untuk mengunjungi Bali. Perbedaan yang ditemukan antara penelitian I wayan Nuriarta dan penelitian ini merupakan latar belakang budaya yang diambil antara kebudayaan Jawa dan Bali, serta media yang digunakan juga berbeda.

Cahyadi Dewanto (2012) dalam penelitian tesisnya yang berjudul "Jejak-Jejak Kassian Cephas dalam Fotografi Dokumenter" sangat menarik untuk menjadi bahan tinjauan pustaka. Dalam penelitiannya, Cahyadi dapat menemukan jejak Kassian Cephas seperti rumah, makam, bahkan nisan yang dibanyak jurnal menyatakan bahwa nisan Cephas telah dibawa oleh koletor. Penelitian ini menyimpulkan bahwa eksistensi karya Cephas dalam bentuk foto tidak lepas dari unsur- unsur kebudayaan dan politik Belanda.

Dalam buku Membaca Fotografi Potret karya Irwandi dan Fajar Apriyanto terdapat ulasan mengenai karyakarya foto potret dari Kassian Cephas. Buku ini memaparkan secara jelas menganai fotografi potret yang dilakukan oleh Kassian Cephas secara terperinci, pembacaan makna,estetika, dan lingkup sosial kebudayaan Jawa pada masa Hindia Belanda dalam fotografi potret. Untuk penelitian ini, buku Membaca
Fotografi Potret sangatlah bermanfaat sebagai acuan tinjauan pustaka. Olivier Johannes Raap dalam buku Soeka Doeka di Djawa Tempoe Doloe, menuliskan banyak mengenai kebudayaan Jawa yang diperlihatkan dalam kartu pos. Olivier banyak menunjukkan latar kebudayaan Jawa yang tercetak dalam kartu pos, selain itu terdapat pula ulasan mengenai Kassian Cephas yang karyanya banyak diterbitkan oleh penerbit pada masa itu. Buku ini terbagi menjadi beberapa bagian seperti, potret wanita dan pria Jawa, keluarga bangsawan, kesenian dan kebudayaan masyarakat Jawa. Buku ini juga menjadi bahan pengambilan sampel pada penelitian ini. Berdasarkan beberapa penelitian di atas, wanita Jawa digunakan sebagai objek dalam penelitian, dengan satu penelitian menggunakan objek wanita dan kebudayaan Bali. Setelah melakukan tinjauan, tidak ada penelitian yang menggunakan objek wanita Jawa dengan metode penelitian semiotika Roland Barthes dan aspek formal fotografi. Ini penting karena menunjukkan konsep penelitian ini belum pernah diteliti sebelumnya, dan penelitian yang dilakukan dalam skripsi ini layak dilakukan. Setiap pemaknaan dalam penelitian tergantung pada pemikiran serta interpretasi peneliti, ini dapat berbeda dari tingkat pemahaman, pengetahuan, serta konsep yang digunakan dari setiap penelitian.

Penelitian ini merupakan penelitian dengan menggunakan metode deskriptif kualitatif. Metode penelitian kualitatif merupakan penelitian yang hasil penelitiannya tidak diperoleh melalui prosedur statistik dan bentuk hitungan lainnya. Metode kualitatif sendiri digunakan untuk meneliti pada kondisi objek yang alamiah karena menyangkut pengertian, konsep, nilai dan ciri-ciri yang melekat pada objek penelitian (sebagai lawannya adalah eksperimen) dimana peneliti adalah sebagai instrumen kunci, teknik pengumpulan data dilakukan secara trigulasi (gabungan), analisa data bersifat induktif atau kualitatif, dan hasil penelitian kualitatif lebih menekankan makna daripada generalisasi.

Setelah melakukan observasi dan pengelompokan sampel data foto yang didapat selanjutnya digunakan sebagai dasar dalam upaya analisis membedah makna menggunakan aspek formal dan teori semiotika konotasi yang telah dikemukakan oleh Roland Barthes. Semiotika mempelajari tanda sebagai cara dalam berkomunikasi, sehingga komunikasi menjadi media yang menyatukan tanda dalam pemahaman semiotika. Semiotika memberikan kesempatan untuk lebih memahami kebudayaan dan orang-orang didalamnya melalui tanda- tanda yang dikomunikasikannya. Untuk itu kajian semiotika melibatkan komunikasi sebagai sarana mencari dan memahami tanda karena tanda tersebut diaplikasikan melalui komunikasi. Teori semiotika Barthes dikembangkan dari teori penanda-petanda yang dicetuskan Ferdinand de Saussure. Saussure merupakan ahli linguistik yang lahir di Jenewa pada tahun 1857. Dari pemikirannya mengenai teori 
linguistik dan semiologi, mengilhami Roland Barthes untuk mengemukakan teorinya mengenai semiologi.

Tanda (sign) merupakan satuan dasar bahasa yang niscaya terusun dari dua relata yang tidak terpisahkan, yaitu citra dan bunyi (accoustic image) sebagai unsur penanda (signifier) dan konsep sebagai petanda (signified). Penanda merupakan aspek material tanda yang sifatnya sensoris, nyata atau dapat diindrai, dan bersifat material entah berupa bunyibunyi, objek-objek, imaji-imaji dan sebagainya. (Budiman, 2003, p. 47). Sementara itu, petanda merupakan aspek mental dari tanda- tanda, yang biasa disebut juga sebagai "konsep", yakni konsep-konsep ideasional di dalam benak penutur. Kedua elemen tanda ini sungguh menyatu dan saling tergantung satu sama lain. Meskipun penanda dan petanda dapat dibedakan, tetapi pada praktiknya tidak dapat dipisahkan: tiada penanda tanpa petanda, tiada petanda tanpa penanda. Kombinasi dari satu konsep dan satu citra-bunyi inilah yang kemudian menghasilkan tanda (Budiman, 2003, p. 48).

Roland Barthes mengembangkan dua tingkatan pertandaan yang memungkinkan dihasilkannya makna yang juga bertingkat- tingkat, yaitu tingkat denotasi dan konotasi. Denotasi sebagai tingkatan pertandaan yang menjelaskan hubungan antara penanda dan petanda, atau tanda dan rujukannya pada realitas, yang menghasilkan makna eksplisit, langsung, dan pasti. Makna denotasi dalam hal ini adalah makna pada apa yang tampak. Denotasi adalah tanda yang penandanya mempunyai tingkat konvensi atau tingkat kesepakatan tinggi. Sedangkan Konotasi adalah tingkat pertandaan yang menjelaskan hubungan antara penanda dan petanda, yang didalamnya beroperasi makna yang tidak eksplisit, tidak langsung, dan tidak pasti (terbuka terhadap berbagai kemungkinan). Misalnya tanda bunga mengkonotasikan kasih sayang atau tanda tengkorak mengkonotasikan bahaya. Konotasi itu cukup kuat karena membangkitkan perasaan dan persepsi tentang segala sesuatu.

Menurut Barthes (Budiman, 2003, p. 71) terdapat prosedur-prosedur konotasi khususnya menyangkut fotografi, antara lain: (1) trick effect, misalnya dengan memadukan dua gambar sekaligus secara artifisial; (2) pose, misalnya dengan mengatur arah pandangan mata atau cara duduk dari seorang subjek; (3) objek, misalnya dengan menyeleksi atau menata objek-objek tertentu (rak buku,misalnya, dapat

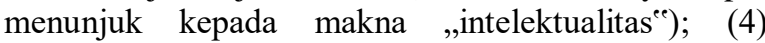
fotogenia, misalnya dengan cara mengatur eksposur, pencahayaan (lighting), manipulasi teknik cetak, dll; (5) estetisme, misalnya dengan menerapkan teknik ,posterisasiee sehingga sebuah foto seolah-olah menyerupai lukisan; dan (6) sintaksis, dengan merangkaikan sebuah foto ke dalam sebuah sekuen (sequence) sehingga penanda dan petanda konotasinya tidak dapat ditemukan pada fragmen- fragmen yang lepas satu sama lain, melainkan pada keseluruhan rangkaian. Prosedur konotasi yang digunakan dalam penelitian ini hanya menggunakan tiga bagaian dari konotator yaitu fotogenia, pose, dan objek.

Salah satu prosedur konotasi yaitu fotogenia lebih merujuk kepada aspek fotografi dengan menentukan aspek teknikal yang terdapat pada foto. Aspek formal fotografi dalam foto antara lain seperti yang dinyatakan oleh Markowski (1984) dalam buku Membaca Fotografi Potret (Irwandi \& Apriyanto, 2012, p. 22) mengklasifikasikan 10 elemen visual dalam fotografi yaitu cahaya (light); nada (tone); bayangan dan bayangan lunak (shadow and cast shadow); bentuk (shape); garis (line); tekstur (texture); perspektif (perspective); ruang (space); dan komposisi (composition). Elemen visual tersebut akan dijadikan bahan analisis untuk sampel foto yang telah ditentukan. Kathleen Francis menyebutkan bahwa terdapat beberapa hal penting dalam sebuah foto potret, yaitu: (1) penonjolan kepribadian/personality, (2) penggunaan pencahayaan efektif, (3) latar belakang, dan (4) pose subjek. Penonjolan kepribadian subjek dapat diartikan bahwa dalam fotografi potret terdapat usaha-usaha dari pihak- pihak yang terlibat di dalamnya untuk menampilkan karakter personal seseorang yang bersifat unik. Karakter personal diposisikan sebagai hal yang begitu penting karena aspek tersebut merupakan variabel pembeda fotografi potret dengan genre-genre fotografi lainnya. Karakter personal merupakan salah satu bagian dari identitas subjek dalam foto potret (Irwandi \& Apriyanto, 2012, p. 6).

Secara umum dalam fotografi potret, pose juga memiliki peran penting dalam menyiratkan makna tertentu. Pose berasal dari kata pausare dalam bahasa Yunani yang berarti, ,istirahat dan berhentice. Kata tersebut dalam bahasa Inggris mengandung beberapa arti seperti: (1) adopt posture dan (2) be pretentious. Jika kedua arti tersebut dikaitkan dengan konteks fotografi potret, arti pertama (adopt posture) bisa jadi berkenaan dengan sikap objek/model yang ditunjukkan secara empiris ketika dirinya diabadikan dalam medium fotografi, sedangkan arti kedua (be pretentious) lebih mengarah pada upaya yang dilakukan untuk menunjukkan sesuatu yang berkaitan dengan sikap, kepribadian, dan aspek nonfisik lain sebagai konsekuensi dari sikap fisik yang dilakukan seorang model berpose secara fisik di depan kamera, berbagai aspek fisik seperti raut wajah, arah pandang, posisi badan, kostum, dan berbagai properti yang menyertainya akan menyiratkan makna (nonfisik) tertentu kepada orang yang melihat hasil foto potret tersebut sebagai konsekuensi dari pose fisiknya (Irwandi \& Apriyanto, 2012, p. 8)

Pose tidak hanya berkaitan dengan sikap badan, namun juga berkaitan erat dengan kostum yang dikenakan model. Pengaruh kostum dalam menyatakan identitas peduduk sangat besar dan sangat menentukan pesan yang akan diterima pengamat karya. Pesan tentang status sosial, etnis, profesi seseorang dapat terbaca dalam foto potret melalui kostum beserta kelengkapan lain yang digunakan 
model (Soedjono, 2006, p. 122). Selain aspek nyata, terdapat pula aspek yang tidak terlihat nyata dalam sebuah foto potret. Aspek tidak nyata dalam konteks ini adalah sesuatu yang melekat pada fotografer dan subjek foto dapat dipahami melalui pendekatan kontekstual atau dengan seperangkat pengetahuan tertentu seperti, latar belakang fotografer maupun subjek, aspek sosial budaya yang melingkupi masa foto tersebut dibuat, dan motivasi atau tujuan dihadirkannya foto potret tersebut.

\section{PEMBAHASAN}

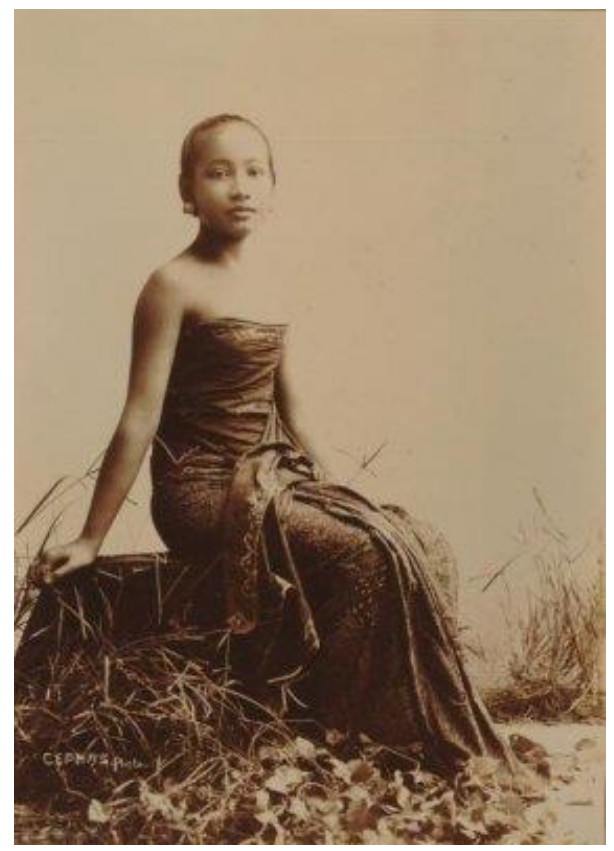

Gambar 1.Javaansche Vrouw

(Cephas, 1910, dalam Raap, 2017;1)

Gambar 1 memperlihatkan potret seorang wanita Jawa yang sedang duduk di sebuah properti yang ditutup kain di antara tumbuhan, menggunakan kemben yang menutupi tubuh bagian atas yaitu dari dada sampai bagian perut dan kain batik panjang yang menutupi bagian perut sampai bagian kaki. Rambut terlihat ditata rapi ke belakang sehingga tidak terdapat satu bagian rambut yang keluar dari kelompoknya. Menggunakan perhiasan berupa anting-anting pada kedua telinga.

Secara fotogenia, pencahayaan pada gambar 1 terlihat pada posisi samping depan yang memiliki karakter cahaya sedang, tidak terlalu keras. Kemungkinan cahaya yang didapatkan merupakan cahaya alami dari sinar matahari, pemanfaatan cahaya matahari sebagai sumber cahaya merupakan hal yang umum pada masa itu dan menjadi pilihan paling praktis juga ekonomis. Pendapat ini diperkuat dengan ekspresi subjek yang terlihat santai, tidak tegang ataupun tampak ekpsresi terkejut pada wajahnya. Penggunaan cahaya buatan atau pencahayaan menggunakan lampu studio memang sudah terjadi saat itu, tetapi karakter cahaya yang dihasilkan menggunakan lampu studio berkarakter keras. Biasanya foto-foto yang menggunakan pencahayaan menggunakan lampu studio membuat ekspresi subjek yang difoto tampak tegang, karena kilatan dari lampu yang dihasilkan sangat keras.

Karakter cahaya sedang dapat dilihat dari bayangan pada bagian wajah samping kanan hingga bawah dagu atau bagian leher sebelah kanan, dan pada bagian lengan sebelah kanan. Bayangan yang terdapat pada sebagian tubuh sisi kanan membuat bentuk tubuh subjek sangat jelas. Tekstur halus terlihat pada bagian latar belakang, bagian rambut yang ditata kebelakang tidak terlihat satu bagian rambut yang keluar dari tatanannya, bagian tubuh yang tidak tertutup kain seperti pada bagian wajah, bahu, dada bagian atas dan lengan, serta pada kain bagian bawah tepatnya pada kaki sebelah kanan juga tampak halus, tidak terdapat lipatan-lipatan dari kain. Sedangkan tesktur kasar dapat dilihat pada bagian kain yang digunakan di bagian dada sampai kain yang menutupi tubuh bagian bawah, terdapat banyak lipatan-lipatan pada kain yang digunakan. Terdapat satu perhiasan yaitu antinganting pada telinga bagian kanan dan kiri yang berbentuk bulat dengan bagian-bagian depan yang menonjol memperlihatkan tekstur kasar. Tumbuhan yang sengaja diletakkan sebagai properti tambahan juga memperlihatkan tekstur kasar dan tidak beraturan. Untuk menyampaikan ide tersebut fotografer secara tehnikal mengambil potret dengan menggunakan sudut pengambilan gambar yang sejajar dengan mata, terlihat pada posisi subjek yang tepat berada lurus di depan. Ruang tajam luas dengan pengambilan gambar yang memperlihatkan keseluruhan bentuk tubuh, dan latar belakang tampak polos membuat subjek menjadi fokus atau titik utama pada foto tersebut. Pengambilan gambar dilakukan secara menyeluruh sehingga seluruh bagian badan subjek terlihat. Ruang ketajaman yang relatif luas menjadi petunjuk bahwa karya foto ini dibuat dengan menggunakan bukaan diafragma kecil. Kombinasi tersebut berhasil menjadikan subjek sebagai fokus utama dalam foto yang juga didukung dengan menggunakan latar belakang yang polos, sehingga saat melihat foto tersebut mata akan langsung tertuju pada subjek.

Posisi tubuh subjek terlihat kaku pada bagian tangan kanan sedikit lurus kebawah, bahu yang dibuka lebar, serta dagu yang sedikit diangkat ke atas. Bagian tubuh bahu sampai kaki menghadap ke samping dengan wajah diarahkan ke depan agar sedikit terlihat. Pose yang sengaja diatur memperlihatkan bahwa fotografer ingin menunjukkan bahwa wanita tersebut merupakan masyarakat biasa, bukan berasal dari kalangan elite maupun bangsawan. Dapat dilihat dari arahan gaya yang tidak kaku dan pakaian yang digunakan yaitu kemben dan kain batik panjang merupakan pakaian yang biasa digunakan oleh wanita yang berasal dari kelas sosial rendah pada masa itu. Bisa dilihat juga pada kostum yang digunakan subjek, wanita Jawa dengan tingkat sosial lebih tinggi pasti 
tidak hanya menggunakan kemben saja tetapi juga menggunakan kebaya sebagai penutup bagian bahu yang terlihat, juga dari perhiasan maupun aksesoris yang digunakan.

Fotografer terlihat ingin menunjukkan bentuk lekuk tubuh dari subjek pada gambar 1 dengan mengatur pakaian yang digunakan berupa kemben dan kain batik panjang, membuat siluet tubuh objek sangat terlihat. Tatanan rambut sederhana yang digunakan dan juga perhiasan yang hanya ada pada bagian telinga, dengan penataan pose, properti pendukung, serta latar belakang yang minimalis merupakan sebuah kombinasi yang tepat untuk menggambarkan kecantikan dan kesederhanaan dari wanita Jawa.

Penambahan properti berupa tanaman dan tempat duduk subjek sebagai pendukung yang merupakan upaya dari fotografer dalam menciptakan suatu ruangan baru pada sebuah foto. Fotografer berusaha menciptakan satu suasana baru yang sengaja dibuat dengan menambahkan tanaman-tanaman pada bagian bawah depan dan samping subjek, sehingga menimbulkan suasana alami pada foto. Kesederhanaan seorang wanita Jawa dari kelas sosial rendah yang coba ditampilkan fotografer terlihat pada beberapa objek yang digunakan, seperti pada tempat duduk subjek dengan menggunakan sebuah properti yang dilapisi oleh kain seolah dia hanya sedang duduk yang sekelilingnya banyak tumbuh rumput-rumput liar, sedangkan pada potret wanita Jawa dengan kelas sosial lebih tinggi atau bangsawan biasanya penataan objek pendukung lebih menunjukkan kelasnya atau lebih bagus.

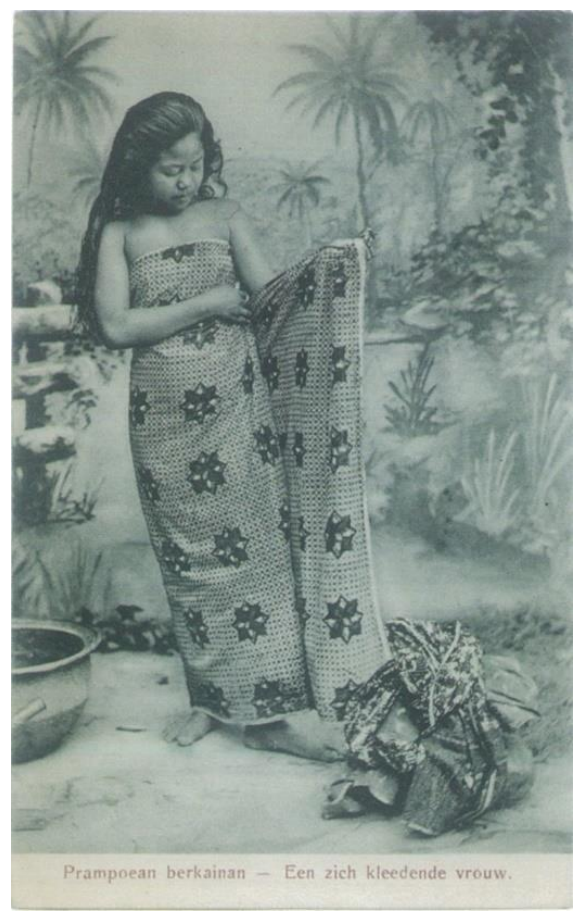

Gambar 2.Een zich kleende vrouw (Ali S Cohan, 1900, dalam Raap, 2017;xxii)
Gambar 2 memperlihatkan foto seorang wanita Jawa yang sedang berdiri terlihat akan melilitkan kain batik panjang yang menutupi bagian tubuhnya. Rambut yang dibiarkan terurai panjang ke belakang tampak sedikit basah. Pada bagian kanan subjek terdapat satu buah wadah yang terbuat dari tanah liat, dan pada sisi sebalah kiri terdapat kain panjang yang diletakkan pada sebuah benda. Latar belakang pada foto kali ini bergambar seperti pemandangan terdapat beberapa gambar tumbuhan, pagar kayu, batu, dan lain- lain.

Secara fotogenia, foto ini menggunakan pencahayaan alami atau cahaya langsung matahari dengan karakter cahaya sedang. Bayangan terlihat pada daerah bawah dagu atau leher dan pada bagian pergelangan kaki. Tekstur halus pada foto terlihat pada bagian kulit subjek yang tidak tertutup kain, pada rambut bagian atas, dan kain panjang yang digunakan subjek. Sedangkan tekstur kasar pada terlihat pada latar belakang yang bergambar beberapa tumbuhan, lantai, sebuah wadah dari tanah liat, dan kain yang ditelakkan di atas properti pada sisi kiri bawah subjek. Pengambilan gambar penuh dari kepala hingga kaki, sehingga seluruh bagian tubuh subjek terlihat, menggunakan ruang tajam luas dan diafragma kecil.

Pada gambar sampel nomor 2 ini, menunjukkan seorang wanita Jawa yang terlihat sedang berdiri tengah melilitkan kain batik pada tubuhnya, dengan rambut yang terlihat sedikit basah dan diurai panjang ke belakang. Posisi subjek yang berdiri dengan wajah melihat pada bagian kain dan tangan yang akan melilitkan kain pada tubuhnya ini menunjukkan bahwa pose sengaja diatur oleh fotografer, seakan subjek terlihat sedang mengenakan kain panjang dan kain panjang yang berada di bawah subjek kemungkinan merupakan kain yang akan digunakan sebagai kemben. Rambut yang tampak basah pada subjek kemungkinan subjek menggunakan minyak rambut yang lumayan banyak sehingga terlihat rambut terkesan basah. Latar belakang bergambar pemandangan yang menggambarkan seakan berada di tempat terbuka. Keinginan fotografer untuk menunjukkan keindahan dari Jawa bisa terlihat pada foto ini, dengan menata pose subjek sedemikian rupa membuat satu kesatuan antara latar belakang yang dipilih, properti, dan juga pose menimbulkan banyak persepsi tentang apa yang sedang dilakukan oleh subjek.

Dengan menggunakan latar belakang bergambar pemandangan dan tumbuhan, dan beberapa properti tambahan seperti, wadah yang sepertinya berisi air, dan penataan kain yang sengaja diletakkan di atas properti dengan tidak berarutan, menunjukkan fotografer sengaja mengatur atau merencanakannya. Fotografer sepertinya ingin menuntun pada persepsi bahwa seorang wanita Jawa yang tampak sedang melilitkan kain batik panjang dengan rambut yang basah dan latar belakang berada di tempat terbuka, menggiring persepsi bahwa wanita Jawa tersebut telah selesai mandi dipinggir sungai. 
Pemaknaan Potret Wanita Jawa Pada Kartu Pos Tahun 1900- 1910, identitas subjek pada sampel foto potret tersebut tidak diketahui secara pasti, tidak ditemukan data tentang nama maupun profesi subjek. Namun subjek wanita-wanita dalam karya foto tersebut dapat diidentifikasikan melalui pengamatan tanda-tanda visual yang terdapat dalam foto. Kecantikan alami dari wanita-wanita Jawa tersebut tampaknya menjadi pesan yang akan disampikan oleh fotografer. Pose yang diatur dan diperagakan oleh subjek mengartikulasikan nilai-nilai kepolosan, kealamian yang khas dari seorang wanita Jawa. Penikmat diajak untuk ikut menikmati sosok ayu khas wanita Jawa, dengan kulit halus dan kencang, serta siluet tubuh yang dibalut oleh kemben dan kain jarik panjang. Pakaian yang digunakan menjadi penanda dalam subjek akan nilai-nilai tradisional yang melekat pada sesosok wanita Jawa. Kehadiran ruang imajinatif yang dibuat oleh fotografer membuat suasana seoleh berada pada suasana tropis. Makna lain yang terpancar dari keempat foto wanita Jawa tersebut tidak terlepas dari eksploitasi fotografis terhadap tubuh-tubuh eksotis wanita Jawa.

Berdasarkan konteks-konteks formal yang telah dijelaskan maka tanda-tanda dalam keempat foto yang sudah diteliti menggiring pengamatnya kepada sebuah representasi eksotis khas wanita Jawa. Sensualitas wanita Jawa pada kartu pos memiliki artikulasi visual yang bisa dikatakan cukup khas. Tidak hanya melihat pada kepolosan dan kecantikan yang ditampilkan, tetapi juga mengundang perspektif imajinasi tentang nilai-nilai sensualitas wanita Jawa pada keempat karya foto.

\section{KESIMPULAN}

Menganalisis makna pada sebuah karya foto dapat dilakukan dengan menganalisis aspek ideasional dan teknikal terlebih dahulu pada foto. Karya foto sejatinya merupakan karya visual yang penuh makna di dalamnya. Pose, ekspresi, objek, pakaian yang dikenakan, serta unsur-unsur visual di dalamnya merupakan adegan yang ingin disampaikan kepada orang-orang yang menikmatinya. Foto wanita Jawa mampu menampilkan imaji subjek wanita Jawa dengan keeksotisannya dengan tetap memperhatikan konsep dan ciri khasnya.

Karya-karya potret wanita Jawa yang dibuat berfungsi sebagai deskripsi visual tentang sisi eksotis dari kehidupan masyarakat Jawa. Penciptaan makna yang dilakukan melalui karya potret wanita Jawa diwujudkan dengan cara menerapkan prosedurprosedur konotatif seperti pengaturan pose, penataan objek, dan fotogenia (aspek formal foto). Pemahaman kultural dalam pribadi setiap fotografer juga turut memengaruhi cara pandangnya terhadap penciptaan karya potretnya, terlihat dari cara menampilkan jati diri seseorang dalam karya potretnya. Foto potret wanita Jawa yang berada dalam kartu pos jelas menjadi konsumsi bagi kelas sosial diatasnya. Wanita yang ditampilkan dalam gambar kartu pos diposisikan sebagai objek yang memiliki keindahan dan daya tarik yang khas. Fungsi sebenarnya pada kartu pos sebagai alat komunikasi berubah menjadi sebuah hasil koleksi dengan nilai nomilal yang disesuaikan dengan gambar yang ada didalamnya.

Kajian ini mengarah pada sebuah kesimpulan umum bahwa berbagai keputusan yang akan diambil dalam menciptakan karya foto potret akan ditentukan oleh tujuan penciptaannya. Dilihat dari sudut lain, penciptaan karya foto potret dapat dipengaruhi oleh latar belakang subjek, aspek sosial dan budaya, ekonomi, politik, dan keadaan masa diciptakannya. Aspek tersebut juga mendasari pemaknaan karya fotografi potret dan genre-genre fotografilainnya.

\section{DAFTAR PUSTAKA}

Barthes, R. (1984). Image, Music, Text. United State of America: Hill and Wang.

Budiman, K. (2003). Semiotika Visual. Yogyakarta: Buku Baik.

Handayani, C. S., \& Novianto, A. (2004). Kuasa Wanita Jawa. Yogyakarta: LKiS.

I Wayan, N. (2016). Kajian Semiotika Pada Poster Bali Di Masa Kolonial Belanda. Prabangkara. JURNAL RUPA DAN DESAIN ISI Denpasar, 19(24), 84-92.

Irwandi, \& Apriyanto, M. F. (2012). Membaca Fotografi Potret. Yogyakarta: Gama Media.

Knaap, G. J. (1999). Cephas, Yogyakarta: Photography in the Service of the Sultan. Netherlands: KITLV Press Koninklijk Instituut voor Taal-, Land- en Volkenkunde.

Raap, O. J. (2013). Soeka Doeka Di Djawa Tempo Doeloe. Jakarta: KPG (Kepustakaan Populer Gramedia).

Sahid, N. (2004). Wanita-wanita korban peradaban priyayi Jawa dalam beberapa karya naratif Indonesia: sebuah kajian sosiologi sastra. Yogyakarta: Fakultas Seni Pertunjukan, Institut Seni Indonesia Yogyakarta.

Soedjono, S. (2006). Pot-pourri fotografi. Jakarta: Universitas Trisakti. 